\title{
Information and Communication Technology: Gender Issues in Developing Nations
}

\author{
Kimberly Betz Leahy and Ira Yermish \\ St. Joseph's University, Philadelphia, PA, USA
}

Kimberley Leahy@yahoo.com iyermish@sju.edu

Abstract

As Developing Nations seek to leverage scarce resources toward the goal of achieving a developed status they must reevaluate past practices and explore available and affordable technologies. Where information and communication infrastructures are weak, use of low-cost, easily distributed technologies have proven effective. Still, many developing nations have failed to incorporate a resource in great abundance, their women, to use these new technologies to greatest advantage. This paper will address the implications of women's lack of economic and educational parity, and offer examples of how the education of women through the use of information and communication technology can enhance a nation's gross domestic product (GDP).

Keywords: Developing Nations, IT Education, Gender Issues

\section{Introduction}

In the space of one generation, Information and Communication Technology (ICT) has changed the global macroeconomic landscape. Business leaders, educators, and politicians all have watched as formerly subsistence economies leveraged ICT to become indispensable knowledge resources to the titular heads of world commerce. Countries that less than ten years ago relied on foreign aid to feed their people, today supply value-added information services to mature and nascent economies alike. Developing nations, whose exports once consisted primarily of raw materials and farming production, now proclaim to the world the technical proficiency of their knowledge workers. Even in societies where ICT has just begun to take root, rural villagers make use of the Internet to bring their goods to the international market.

Nations that capitalized on the information technology age have recognized significant return on their initial ICT investments. We as an interdependent global community have experienced in real terms the positive economic change that shared understanding and open communication have fostered in formerly marginalized societies. With ICT, the knowledge required to make economic revolution happen can now be accessed by developing nations, bringing about a level of education and economic opportunity hitherto unimagined.

Material published as part of this journal, either on-line or in print, is copyrighted by the publisher of Informing Science. Permission to make digital or paper copy of part or all of these works for personal or classroom use is granted without fee provided that the copies are not made or distributed for profit or commercial advantage AND that copies 1) bear this notice in full and 2) give the full citation on the first page. It is permissible to abstract these works so long as credit is given. To copy in all other cases or to republish or to post on a server or to redistribute to lists requires specific permission and payment of a fee. Contact Editor@inform.nu to request redistribution permission.
The economic benefits of an educated society have long been tied to improved standards of living; numerous studies have linked the two, and few would argue that the increased wealth of a nation's people is not a positive externality of education. Over the past ten years, ICT has contributed to increased education levels, and, by implication, income levels, around the world. From introducing distance learning to the first-time student in a developing nation, to job-skill training in 
countries resurrecting their domestic industries, ICT has facilitated communication and vital knowledge transfer across six continents.

Still, even with the accessibility to educational resources that ICT represents, some countries elect not to take full advantage of ICT's potential with respect to nearly half their own people. Women, on average, represent fifty percent of a given nation's populace; yet in most developing countries, women represent far less than fifty percent of the nation's intellectual capital, skilled labor pool, and economic contribution. For reasons beyond the scope of this discussion, some nations do not afford the same freedoms and opportunities for education to all their citizenry. Consequently, these nations overlook fifty percent of their most valuable natural resource: human potential. Developing nations experiencing skilled labor shortages have heard their women express the desire and ability to learn and work. However, in many countries, strong cultural prohibitions still exist against educating women and allowing them access to employment. These same countries lament their dearth of communication technology workers, even as they hear their women beg to be given economic opportunities. That extending opportunity to women results in a lessening of opportunity for men is a specious argument. When a country fully leverages all its assets, discovery leads to innovation, resulting in greater opportunity for everyone.

Women represent three quarters of all heads of households in developing nations, and for every one woman in poverty there are four children, (UNICEF, 2001). Perhaps out of habit, developing nations have continued to spend scarce economic resources on the consequences of illiteracy, yet have not taken the one step that could solve the problem in one generation: educating their women.

World leaders have for decades asserted education as a basic human right. The rulers of some developing nations have felt otherwise. The following discussion recognizes and affirms the importance of a country remaining true to its culture; it would demonstrate unqualified hubris to recommend the export of Western values as a model for achieving economic parity across nations. Economics alone cannot measure the worth of cultures dating back thousands of years. Still, the basic human right of education as upheld by the United Nations is being denied to women in many developing nations, often to the economic disadvantage of those nations. This paper will not be another shrill voice for the world's despots to apply Kantian principles toward the equal governing of their people. Nor will it suggest that but for women's educational disenfranchisment, the economic crises of the world would be resolved. This paper will, however, offer a compelling argument to incite world leaders to educate the full complement of their respective societies.

By first outlining the costs of female illiteracy, both to today's generation and to its progeny, then citing concrete examples of economic turn-around in societies offering equal educational opportunity to women, this paper will illustrate the economic imprudence of a country's refusing to educate every last one of its willing and able adults. The discussion will include a summary of the state of women's education around the globe and its concomitant poverty. It will offer communication technology-based, knowledge transfer solutions to most expeditiously provide women with educational opportunity. The discussion will give examples of organizations, both government and non-government, available as resources to developing nations wishing to endow women with the rights of education and employment. It will cite numerous quotations from authorities in global economic and educational policy concerning the undeniability of the value of women's education. It will show where success toward those goals has been achieved, and examples of where women's use of ICT in the developing nation workplace could successfully be applied. This discussion will indicate how through organic growth as well as foreign direct investment, a nation might bring about positive economic change by opening opportunity to its entire people. This paper will not judge any nation's culture, politics, or economic condition. This paper will only offer alternatives to current economic and educational practices, and illustrate how information communication technology might foster positive change. Clearly, offering women educational opportunities alone will not provide complete economic turnaround for all developing nations. Yet it remains an area untried and one with proven outcomes. 


\section{Women, Poverty and Education}

Women are still the poorest of the world's poor, representing 70 percent of the 1.3 billion people who live in absolute poverty, (Data and Statistics, 2001). Nearly 900 million women have incomes of less than one US dollar per day, (UNESCO, 2001) the equivalent of the population of the United States times three. In the world today, 880 million people are considered illiterate; that is, as defined by the $\mathrm{UN}$, the inability to read 40 words per minute, write 20 words per minute, and do two-digit arithmetic, (UNESCO, 2001). Two thirds of the world's 880 million illiterate are women, a statistic that has remained unchanged for ten years, (UNESCO, 2001). For these 590 million women and their respective countries, the correlation between literacy and economic contribution cannot be overstated. Concerning the link between women in poverty and literacy, World Bank President James D. Wolfensohn, in his speech to the World Education Forum in Dakar Senegal, April 27, 2000, said, "No country has succeeded without educating its people; education is key to sustaining growth and reducing poverty. Countries that have invested in education for women as part of their educational priorities, and as part of an integrated approach to societal development have seen slower population growth, faster economic growth, and a higher level of social cohesion. It is time for all countries to put aside their doubts and fears about educating women, and give it the highest priority. Culture that denies choices to women and girls must be changed" (Wolfensohn, 2000).

Despite calls for educational equality for women, many developing nations still adhere to cultural mores that relegate women to manual tasks performed inside or just beyond the walls of the home. No effort is made to incorporate women into the country's economic equation, and this disparity is reflected in the country's overall GNP. Many societies only evaluate women's contribution in terms of being a good wife and mother, without offering women choices outside the home. Education of women has no value, it is believed, as the women have no need for knowledge if their only role is a domestic one. United Nations Secretary General Kofi Annan admits with regret that, "When parents consider their daughter's future, they often see education as a hindrance, not a help, to successful marriage and motherhood" (Annan, 2000). Societies with such outdated mindsets suffer needlessly as a result of the illiteracy of the mother. The consequences of her ignorance are visited upon future generations.

In Nepal, a system of patriarchal and misogynistic practices still pervades society. Women typically provide upwards of 75 percent of the food consumed by their families, (UNFPA, 2001) but because their labor toward this end is unpaid, it remains invisible, and therefore is not counted as part of household contribution nor overall national economic contribution. Despite their significant role in providing the majority of their family's food supply, women feed their husbands and boy children before feeding themselves. During times of scarcity, women go hungry, (UNFPA, 2001). Nepal's illiteracy rate for women is 76 percent; for men, the rate is 41 percent. The country's per capita GDP is US\$220 (World Bank Group, 2001).

In his remarks at the International Consultative Forum on Education for All, April 28, 2000, the Honorable Gene B. Sperling, US Assistant to the President for Economic Policy, stated, "Education truly is the closest thing we have as an answer for the universal quest for economic opportunity, and it must be at the center of any long-term strategy for economic development and poverty reduction. Most importantly, education is every woman's right. To forget this is to imperil our global future" (Sperling, 2001).

In Yemen, though women work 30 percent more hours per day than men, (UNFPA, 2001), women account for only two percent of Yemen's economic activity, while men account for 81 percent, (World Bank Group, 2001). How can women work more hours than men, yet contribute so little to a country's economy? Women typically work in domestic labor - hauling water, tending to small gardens, toiling over household chores and caring for children. When a woman is able to earn some money outside the home, she turns it over to her husband, or her father or brother, as she cannot by law own property, (UNFPA, 2001). Of course, after she has completed a full day's labor, her work in the home continues, 
without the help of the men, $(U N F P A, 2001)$. In Yemen, the illiteracy rate for women is 74 percent two and a half times that of men. The corresponding per capita GDP is US\$326, (World Bank Group, 2001). By comparison, Mauritius, a country that introduced free education for all in 1977 has a GDP of US\$ 3638, and an illiteracy rate of only 19 and 12 percent for women and men, respectively, (World Bank Group, 2001).

The Honorable Maria Minna, Canada's Minister for International Cooperation, in her speech on April 28, 2000, in Dakar, Senegal, asserted that, "Never before in human history have we been so well equipped to achieve our goal of educating girls as well as boys. It's now our responsibility to do everything in our power to make universal education a reality. Educating women will change the world as we know it" (Minna, 2000). Strong evidence exists to support this idea. In his book Wealth of Nations, Adam Smith outlined how greater efficiency produces greater wealth. Education contributes to process efficiencies, which in turn lead to sustainable development. Even at the most fundamental level this principle applies.

A woman who can write need not waste time traveling from location to location, gathering the materials she needs to weave the clothes she sells at the bazaar. She can send for the materials, and instead spend her time weaving, not traveling and hauling or waiting for the itinerant peddler to come to her village with supplies. She can advertise her wares and draw customers from previously untapped markets. The woman who can read can learn new ways of generating additional sources of income. If she possesses basic math skills, she can trade in currency, not in kind, giving her liquid assets with which to conduct future business. As such, an educated female can contribute to a country's economy. She can provide for her family without requiring charitable assistance, and her country realizes a net gain from her economic contribution. It no longer must factor the care of that women and her family into the national budget.

When a country no longer must allocate funds toward the Sisyphean task of fighting poverty's legacy, it can proactively manage its resources, redirecting funds toward revenue producing enterprise. Mahathir Mohamed, former Prime Minister of Malaysia, a formerly underdeveloped nation which since 1996 has attracted technological investment from over 350 Multinational Corporations, aptly stated that, "It can be no accident that there is today no wealthy developed country that is information poor and no information rich country that is poor and under-developed." (Mahathir, 2000).

If developing nations wish to be ranked among the world's independently successful, they must initiate change that will open opportunity for the women of society, with the understanding that non-oppressive traditions can co-exist alongside contemporary norms. The Retired Honorable Clare Short, Secretary of State for International Development, in her speech to the World Education Forum, in Dakar, Senegal, April 28, 2000 showed the way to making these universally recognized, necessary changes happen. "The world is entering a new phase in its economic history. The new technologies are creating a new knowledge-based economy. If we do not make very rapid progress in education for those who are excluded, the poor of the world will be even more marginalized in the world economy. Capital is now plentiful. The new technologies can be made available to any country that organizes itself in a way that attracts inward investment. And that investment will create the possibility of the rapid economic growth essential to the reduction of poverty. But these benefits will only flow to the countries that educate all their people." (Short, 2000).

\section{Technology and Education}

Numerous methods for information delivery exist to bring communication technology to communities where, less than five years ago, no method beyond face-to face- discourse existed to convey information. The information and communication technology advances of recent years have given us unprecedented 
connectivity to some of the most remote locations in the world, places that do not even have a written language.

When working in societies such as these, an educator naturally must learn to communicate with a woman in her native language before any knowledge transfer can occur, a very difficult task when there are no written materials to study. ICT helps bridge the language barrier and facilitate learning. A service organization called SIL International has carried out linguistic work in 1,320 languages spoken by 350 million people in more than 50 countries, including developing writing systems for more than 800 languages. Educational materials in both print and electronic format have been written, published, and distributed in more than 1,200 languages. SIL International can generate computer based translation materials to train the educators who work in the field with the women from these remote locations. The educator's goal is to enable the women in these villages to use the training programs themselves to continue to bring literacy to other women in their own language. SIL's belief is that, "The ability to read is not an isolated intellectual skill, but the key to development at the personal, local and national levels" (SIL, 2001).

Having the ability to read and write is still not sufficient to be able to enjoy the full benefit of literacy. Mathematics and the ability to reason round out the literacy equation, but many women in developing nations have had no exposure to even remedial mathematical concepts. In some cases, an idea as simple as counting may have to be taught before any math can be demonstrated. Numerous programs exist to bring mathematical concepts to students everywhere. One example is the Eisenhower National Clearinghouse (ENC), which has compiled on-line mathematics coursework to address math skill levels from pre-remedial through applied mathematical concepts (Eisenhower National Clearinghouse, 2001). To bring these concepts to women and men from developing nations, ENC partners with the Education Development Center (EDC), a nonprofit company that designs educational systems and sponsors more than 325 educational projects around the globe. EDC can address educational needs from the most remedial, through professional development and job training (Education Development Center, 2001). Not all ICT comes only in the high-end, application oriented training modules with which most professionals from developed nations have become familiar. These two organizations and others like them can impart knowledge even to adults whose educational needs have been neglected all their lives.

Further inroads have been made to bring educational resources to areas where prior to the Internet, no cross-cultural knowledge transfer had ever occurred. Universities are partnering with non-government organizations to offer Internet- based coursework to developing nations. In Senegal, for example, two secondary schools received training in computer use and Internet applications, and then were connected via the Internet to corresponding schools in Quebec, Canada. For the first time in the history of SubSaharan Africa, students could engage in real-time communication using the Internet. The Senegalese students and their Canadian counterparts even participated in the Global Knowledge Conference in Toronto with World Bank President James D. Wolfensohn (Senegal, 2001). For countries in every stage of development, today's ICT's create avenues for cost effective, sustainable change.

As knowledge transfer agents, the Internet and distance learning tools are routinely combined to bring information to developing nations. Local and Wide Area Networks, internets, intranets, and extranets, wired and wireless connectivity for telecommunications, and educational data applications have given millions of people around the world access to multimedia distance learning. Electronic mail, topicspecific chat rooms, and on-line virtual communities support the entrepreneurial efforts of men and women in nations around the globe. With the proliferation of ICT's, there are as many levels of sophistication for the delivery of information as there are levels of experience in end users.

The following is an excerpt from an article by Larry Moulds (Moulds, 1996).

'From the standpoint of the end user, ICT's and distance learning models offer the following potential advantages: 
Information and Communication Technology

1. Reduced learning time - typically $30-40 \%$ less time is required compared to classroom instruction.

2. On-demand learning - instruction is available when and where the learner needs it. No need to wait for or travel to a scheduled class.

3. Increased achievement - when corrective feedback or a mastery learning strategy is provided, students often show better test results, retention, or job performance from technology-based interactive learning.

4. Better quality control - since learning experiences are delivered in the same way each time, [they] are much more consistent and reliable than classroom instruction.

5. Increased safety - learners can learn about and practice dangerous procedures without a safety concern.

6. Greater flexibility - fluctuations in the number of learners or their backgrounds can be accommodated more easily than with classroom instruction.

7. Improved accountability - automatic collection of data on learner performance can verify learning accomplished and identify learning problems.

8. Faster revision - to the extent that the learning experiences are delivered via a networked system, changes and updates to information can be made immediately.

9. Reduced delivery costs - once developed, technology-based interactive learning is likely to cost less relative to labor- intensive classroom instruction. It can also be used instead of expensive equipment.

10. Learner controlled - each learner is able to review topics or to skip beyond the information they already know.

11. Increased motivation - students usually report that they find technology-based interactive learning more enjoyable"

With these advantages in mind, it is easy to see how developing nations can leverage ICT, assisting not only women but all people in breaking through the digital divide toward greater productivity and overall well-being. Among the technology enabled instructional media used in developing nations, the following stand out as the most flexible and readily deployed (Chief of Naval Operations, 2001):

$\begin{array}{ll}\text { Slide Shows and Linear Computer-Based } & \text { Fully Interactive Simulations } \\ \text { Training } & \text { ITS and Artificial Intelligence } \\ \text { Interactive Radio } & \text { Adaptive Learning Systems } \\ \text { Interactive Television } & \text { Automated Electronic Classrooms } \\ \text { Multimedia-Based Training } & \text { Instructor Controlled Electronic Presentation } \\ \text { Drill and Practice } & \text { Systems } \\ \text { Learner-Selected Branching } & \text { Interactive Electronic Technical Manuals } \\ \text { Canned Simulations } & \text { Electronic Workforce Training Portfolios }\end{array}$

\section{Organizations}

Most programs designed to meet the needs of women in developing nations can be implemented by nongovernment organizations (NGO), allowing developing nations to direct their scarce budgetary funds toward revenue producing endeavors. The World Bank defines NGO's as "private organizations that 
pursue activities to relieve suffering, promote the interests of the poor, protect the environment, provide basic social services, or undertake community development" (World Bank Group, 2001).

The definition goes on to say, "In wider usage, the term NGO can be applied to any non-profit organization which is independent from government. NGOs are typically value-based organizations that depend, in whole or in part, on charitable donations and voluntary service. Although the NGO sector has become increasingly professionalized over the last two decades, principles of altruism and voluntarism remain key defining characteristics" (World Bank Group, 2001).

The significance of the involvement of NGO's in developing countries is that aid to the needy of society does not depend at all on government funds. Non-profit NGO's obtain their contributions through private sources, usually from individuals and institutions that have interests and areas of focus similar to the NGO's. A recent statistic puts contributions to NGO's at nearly US\$10 billion per year (World Bank Group, 2001). This not an insignificant sum, and in cases of developing nations, NGO's have done much to improve to lot of women in society. Though certainly not exhaustive, below is a list of some NGO's that have seen success in helping women of developing nations leverage ICT in pursuit of economic independence:

Acacia - "Aims to demonstrate, test and promote community-based ICT applications for rural community development and empowerment, in ways that build upon local goals, cultures strengths and process."

APGEN - "To promote gender equality by developing policies and programs that ensure equal opportunities and access to resources for women and men, and their equal participation in economic and political decision-making. Demonstration of new technologies through piloting, collecting, analyzing, documenting and disseminating innovative approaches."

Women's Net - "A vibrant and innovative networking support program designed to enable South African women to use the Internet to find the people, issues, resources and tools needed for women's social activism."

In addition to NGO's, the United Nations sponsors international organizations committed to, among other topics of critical concern to the world community, advancing the betterment of women on the global front. Both sets of organizations work with women in developing nations to set up classrooms, supply computers, materials and instructors, pay for Internet connectivity, formulate job training programs, and manage support programs for ongoing knowledge retention and job skill application. Below is a brief list of some of those UN organizations and their visions.

ITU - International Telecommunication Union: "Headquartered in Geneva, Switzerland, ITU is an international organization within which governments and the private sector coordinate global telecom networks and services"

UNICEF - United Nations Children's Fund: “Aims, through its country programs, to promote the equal rights of women and girls and to support their full participation in the political, social, and economic development of their communities."

UNESCO - United Nations Educational, Scientific, and Cultural Organization: "To contribute to peace and security in the world by promoting collaboration among nations through education, science, culture and communication in order to further universal respect for justice, for the rule of law and for the human rights and fundamental freedoms which are affirmed for the peoples of the world, without distinction of race, sex, language or religion."

UNFPA - United Nations Population Fund "Recognizes that all human rights, including the right to development, are universal, indivisible, interdependent and interrelated" 
World Bank Group: “One of the world's largest sources of development assistance. In fiscal year 2001, the institution provided more than US\$17 billion in loans to its client countries. It works in more than 100 developing economies with the primary focus of helping the poorest people and the poorest countries."

\section{Technology's Success Stories}

We need Organizations such as these to help affect positive change for women in developing nations. Teaching women in developing nations the ways of leveraging technology for economic gain has had profound and diverse impact. One example is a story from Guyana, where information technology changed the business landscape of a remote rural community of about 2,000 inhabitants who did not have telephones until 1999.

The women of a village in Guyana had just revived the ancient art of hand- weaving large hammocks when Guyana Telephone and Telegraph installed an innovative satellite system. The company gave the women of the Weavers Society $\$ 12,000$ dollars worth of computer equipment, free access to the information superhighway, and also paid to have one of the weavers trained in Internet applications.

With the creation of a website, in 1999 the Guyana weavers year sold 17 hammocks worldwide for about US\$1,000 each (Heyzer, 2000). In 1999, the country as a whole only had a per capita GDP of $\$ 854$ (World Bank Group, 2001).

Another example is of Dorcas Kabusomba, a small-scale farmer in Uganda and 46- year old mother of nine. In 1998 by the Uganda National Council of Science and Technology (UNCST) introduced the Nabweru Community Telecentre (NCT), a pilot ICT project, and one of the many ICT projects funded by the International Development Research Centre (IDRC) under the Acacia initiative. The telecentre has established relationships with agricultural research centers in Uganda, going to the communities and collecting information from farmers on what they need to improve their processes. In most cases the information required is about a particular livestock disease, or how the farmers could increase their production. The questions are then e-mailed to research the centers, and when the responses come back with the advice on how to solve the problem, the information is shared with the farmers.

According to Ms. Kabusomba, using the information she has been able to obtain through the telecenter, she has been able to learn new methods of producing maize, fodder and sweet potatoes, as well as how to carry out effective zero grazing and poultry keeping. Ms. Kabusomba says, "At the moment I have 200 broilers which sell at Ush 3500 (US\$ 2.36) each and one Friesian dairy cow that gives me twenty litres of milk per day, which I sell for Ush 600 (US\$ 0.4) per litre. Before I started getting the information from the Web at the telecenter, I was not able even to feed my children" (Okwembah, 2000).

Ms. Kambusomba's annualized income is now upwards of US \$3000, in a country whose per capita GDP is only US\$310 (World Bank Group, 2001). To continue success such as Kabusomba's, Acacia plans to identify women entrepreneurs around Nabweru, determine their training and information needs, and then train them in the use of ICTs. Acacia will work hand in hand with the Council for Economic Empowerment of Women in Uganda on business training for the women.

Not just Internet technology has positively impacted developing nations. In Bangladesh, the Grameen Bank is sponsoring the proliferation of cell phones, and plans to wirelessly enable 40,000 of the country's 68,000 villages by 2004 . A pilot program involving 150 villages has confirmed that the village phone concept is economically viable. Grameen Bank had already had success with their micro-loans program involving women in Bangladesh who needed the bank's help in starting small businesses.

Grameen Telecom, the telecommunications arm of Grameen Bank, selects women for the village cell phone operator projects based upon the women's past borrowing records with the Bank. 94 percent of all of Grameen Bank's borrowers are women, so as a result, women almost exclusively operate the phone 
service in these villages. The women, it turns out, need only one day of training from Grameen Telecom. Their success in rapid training and in their business has to be at least partly attributed to their general entrepreneurial skills and the confidence they have built through their past income generating businesses with the help of the Grameen Bank.

Some of these women have set themselves up as their village's communication link. For a small fee, villagers may use the cell phone, located perhaps at a market food stall. For slightly more, the woman operator will bring the phone to the villagers and let them use it in their homes. Each of the village operators is making $\$ 2$ per day on average, or $\$ 700$ per year, after covering all her costs. This earning of more than twice the country's annual per-capita income is a proof that phones are being put to good use in these villages. There is also a great deal of social impact due to this new service. Some of the poorest women in the villages hold in their hand instruments of global communication, the great equalizer. Even a relatively rich person in the highly socially stratified village is walking up to a poor woman's home for a communication service he needs (Carbonara, 1997).

According to World Bank data, including those by International Telecommunication Union, a poor economy like Bangladesh would grow by $\$ 4,000$ annually in GNP with the introduction of each additional phone (World Bank Group, 2001). The phone itself would cost only a $\$ 1,000$ to install, with the price, like other microchip based technology, declining every year (International Telecommunications Union, 2001).

Success stories like these of implementing communication technologies are not isolated cases. In Ghana, where the per capita GDP is US\$350, (World Bank Group, 2001) market women in the north can save a four- day round trip and gain valuable productivity time by making one phone call to place an order for market delivery (Women's Net, 2001). If, conservatively, she typically makes her market trip just once a month to buy goods to sell or for the materials to create the goods she sells, she has gained an additional 13 percent productivity with one phone call. This assumes that the trips themselves are all productive and that what the woman traveled to find is even available. Farmers in India who must travel to fertilizer distribution centers return home empty-handed $31 \%$ of the time because supplies are not available (Women's Net, 2001). In Peru, telephone subscribers in peripheral areas to Lima save ten times their yearly subscription in transportation savings (Women's Net, 2001).

An Asian Development Bank study in Thailand identified an economic valuation factor for this communication technology of 2.58 , meaning that the benefits of one telephone call was worth more than twice the amount paid for the call (APGEN, 2001).

\section{Large Scale Applications}

To this point, examples of communication technology inputs and their economic impact on developing nations have addressed only local, small-scale technological deployments. Large-scale applications have an even greater and more far reaching impact. Egypt is one prime example.

Egypt, the most populous Arab nation (International Telecommunications Union, 2001), plans to become a leading software exporter. A recent survey by the Research Unit of Internet Arab World magazine estimated that at the close of the millennium, the number of Internet subscribers in the Arab world exceeded half a million, and Internet users numbered two million, including 400,000 users in Egypt (Jarrah, 2000). Abdul Kadir Kamli, editor- in- chief Internet Arab World (IAW) and the Arabic edition of PC Magazine, Middle and Near East, estimates that the Middle East region will have upwards of 12,000,000 Internet users by 2002 (Jarrah, 2000). One area where Egypt feels it could have a measurable impact in ICT is in translating software from English to Arabic for users in the Middle East region ("Work like," 2000), a potentially vast market with some 175 million speakers of Arabic, the sixth most spoken language in the world. 
Information and Communication Technology

"Egypt is traditionally the intellectual capital of the Middle East and Arab-speaking countries, and is where a lot of the content in media is produced." Communications Minister Ahmed Nazif told Reuters ("Work like," 2000). "The same way that it leads the Arab world in producing media content - books, films and broadcasting - Egypt feels it can lead in electronic content development."

One problem, however, is that English is rarely understood outside of Egypt's elite, and the country has an overall illiteracy rate of 45 percent (World Bank Group, 2001). The government very recently made English language courses a mandatory part of university curriculum, but it still has not addressed English proficiency at the grade school level, where language skills are traditionally best formed.

Beyond just translating English programs into Arabic, Egypt hopes to become the Silicon Valley of the Middle East. In early 2001, Minister Nazif announced the creation of Egypt's first information technology Business Park, or "smart village", planned for construction in Giza, in the outskirts of the capital Cairo. The government has four others in the planning stages, with the intention of repeating the model across the country. Smart villages will mimic the United States' Silicon Valley in that they will be industrial centers devoted to the development of software and related technologies. The plan is for smart villages to be self-supporting communities, complete with businesses, shopping, restaurants and cultural attractions ("Work like," 2000).

Egypt's government has poured considerable resources into making this plan a reality. President Hosni Mubarak has allocated substantial amounts of government land for the Giza project and given Giza and all subsequent smart villages a 10-year tax break. On October 1, 2001, the government reduced the cost of local leased lines for Internet service providers by upwards of 60 percent ("Work like," 2000).

Egypt's official National Plan for Telecommunication and Information calls for the creation of an Egyptian Software Export Development Organization to help increase software exports to US\$ 500 million by 2005. A lofty goal, since, in 2000, the value of the Egyptian computer software market was estimated only at around US\$ 50 million (International Telecommunications Union, 2001). Still, Egypt is taking the idea of becoming a global ICT powerhouse very seriously.

In order to achieve a ten fold increase in software exports in only five years, Egypt will need 30,000 IT specialists. The National Plan proposes the establishment of a National Institute of Information Technology capable of graduating 5,000 students a year, a five-fold increase over Egypt's current IT training capacity of only 1,000 students a year. Alliances with ICT firms such as IBM, Intel and Cisco will aid in upgrading Egypt's ICT education program. Agreements with these companies aim to train 5,000 professionals a year to develop ICT and allow Egypt to compete in international markets. Whether this effort will be significant enough soon enough remains to be seen. Although the country has over a dozen universities, most Egyptian college graduates do not have specialized computer skills. The country's 200,000 computer trainees learn only basic application packages or simple skills such as data entry. Egypt has just 10,000 skilled computer workers who qualify as programmers and system engineers, and, according to Dr. Abdel Hamid Abed, Chairman of the Egyptian Software Consortium, this number needs to be tripled (Howeidy, 2000).

According to Minister Nafiz, Egypt had seen heavy investments in ICT over the first twelve months of the new millennium, attracted partly by a big local market in a population of 65 million. For instance, the Ministry of Communications and Information Technology signed an agreement whereby Cisco would train 1,000 Egyptian ICT students a year, with two training academies being established in Egypt that could later become a hub for Cisco training in the Arab and Africa regions ("Egypt's Ministry," 2000). The first stage of this program began in May 2001 beginning with Egyptian instructors being trained in Cisco locations in the US and Europe.

Not only Cisco is involved in Egypt's plan for ICT dominance. In 2001 a second deal was forged with IBM. IBM will contribute over US\$44 million and train 3,000 Egyptian students a year in six-month courses at IBM training centers located in Egypt. Students in the top ten percent of each class will be 
trained a further six months at IBM computer labs around the world (IBM Learning Services, 2001). Intel, too, has a stake in Egypt. In 2001 it won government approval for a $\$ 500$ million project to build a microchip plant that will result in the creation of 3,000 new jobs, primarily in technology ("Intel eyes," 2000). To buttress the inflow of foreign direct investment, Egypt's private sector has pledged \$26 million for the Giza development, which it will run (“Egypt plans,” 2001).

It would seem with such heavy investing in Egypt's information and communication technology that the country has a bright future. But Egypt has one big problem: its educational system. The country's National Plan for Telecommunication and Information states: "Human resources are considered the most important component in the communication and information industry." The government plans to spend over US\$ 100 million through June 2002 on human resource development projects in the high tech sector ("Egypt plans," 2001). This investment is not misplaced. Taher Gargour, an equity analyst at HSBC, said "What Egypt critically needs is a real improvement in its education system" ("Work like," 2000). Thirty-three percent of men and fifty-six percent of women in Egypt are illiterate (World Bank Group, 2001).

It should be fairly stated that Egypt is one of the most progressive Arab countries when it comes to women's rights, and it certainly is one of the most modern countries in the Middle East. The following commentary is in no way meant to castigate the Egyptian government or culture, but only to point out that female inclusion in the economy and workforce could help quickly further the country's aim of becoming an ICT global powerhouse.

Independent consultants and Government Ministers have agreed that the success of Egypt's plan for the country's economic future depends on skilled workers. Hindering forward movement toward Egypt's goals is the nation-wide shortage of tens of thousands of skilled ICT workers. As a demographic that constitutes only ten percent of the workforce (World Bank Group, 2001), women represent one obvious solution for the labor shortfall. Still, in Egypt women's work is a controversial issue. Most women's work such as domestic work, farm work and work in family enterprises is not included in the definition of economic activity. Women's economic opportunities are fewer than men's and social pressure against women pursuing a career is heavy (Acacia, 2001). Yet at a critical time in Egypt's technological and economic development, the undeniable need for skilled ICT workers makes a compelling case for inviting women to join ICT educational and employment.

As an untapped market, Egypt could select the best and the brightest of its women to participate in the training programs offered by the multinational corporations investing in the country's ICT ventures. With the labor shortage having reached critical proportions, Egypt need not worry that preparing a woman for a position in ICT would result in a man sitting on the sidelines.

The ICT industry in Egypt is not a zero-sum game. Egypt currently has so much pent up demand for skilled ICT labor that no concern exists for gender-based job rivalry. Scarcity overrides competition. Women bringing their intelligence and enthusiasm for working to the ICT field could only improve Egypt's chances for international ICT success.

\section{Conclusion and Future Research}

The Economist notes that, "Educating more women in developing countries is likely to raise the productive potential of an economy significantly." Egypt's per capita GDP is US \$1490, and one fifth of the population lives below the poverty line (World Bank Group, 2001). Minister Nazif has estimated that "The value added by each professional is about $\$ 100,000$, which means half a billion dollars added to GDP every year" ("Work like," 2000). With today's count of over 30,000 vacant ICT jobs, the opportunity cost of Egypt not including women in their economic equation is high. 
This paper has just begun the process of addressing these issues. Future research will develop detailed longitudinal studies of nations as they move forward and compile more extensive statistics demonstrating the validity and efficiencies of a number of information and communications technologies and the role of women in their effective use.

\section{References}

Acacia [Organizational website] www.acacia.org accessed October 30, 2001.

Annan, K. (April 26, 2000). Building a partnership for girl's education. Keynote address to the World Education Forum, Dakar, Senegal www.unesco.org/education/efa/wef_2000/speeches/secretary_general.shtml, accessed October 13, 2001.

Apgen [Organizational website] www.apgen.apdip.net accessed October 2, 2001.

Carbonara, P. (December, 1997). Here's a business plan to fight poverty" Fast Company www.fastcompany.com/online/12/fightpoverty.html accessed October 22, 2001.

Chief of Naval Operations, (CNO) Office of training technology; seamless product information, data exchange, and repository (OTT SPIDER) [Agency website] www.ott.navy.mil accessed October 6, 2001.

Data and Statistics. (2001). World Bank Group. http://www.worldbank.org/data accessed on October 12, 2001.

Educational Development Center [Agency website] www.edc.org accessed November 9, 2001.

Egypt plans smart villages in drive to become regional technology hub. (January 31, 2001). Edinvest. http://www1.worldbank.org/edinvest/docdetails.asp?doc_id=23\&searchonly=1 accessed November 9, 2001.

Egypt's ministry of communication and it signs agreement with Cisco Systems. (April 26, 2000). Gitex Cairo Online www.gitexcairo.com/2000/press/apr2600.html accessed November 10, 2001.

Eisenhower National Clearinghouse [Agency website] www.enc.org accessed November 9, 2001.

Heyzer, N. (July 11, 2000). Unifem and information technology. Earth Times News Service www.earthtimes.org:80/jul/technologyunifemandinformationjul11 00.htm accessed October 7, 2001.

Howeidy, A. (March 30 - April 5, 2000). On the wings of IT. Al-Ahram Weekly www.ahram.org.eg/weekly/2000/475/ec3.htm accessed November 10, 2001.

IBM Learning Services, Egypt [Corporate Web Site] http://www-5.ibm.com/services/learning/eg/tairis.nsf/(ExtFileName)/extgrad accessed November 10, 2001.

Intel eyes Middle East for growth. (June 8, 2000). Arab-American Business http://www.arabamericanbusiness.com/issue8_june/mw_intel.htm accessed November 8, 2001.

International Telecommunications Union [Agency website]www.itu.int accessed October 22, 2001.

Jarrah, F. (March 7, 2000). Number of Internet users in Arab countries edges toward two million. DITnet www.ditnet.co.ae/itnews/newsmar2000/newsmar20.html accessed November 8, 2001.

Mahathir, M. (June 27, 2000). Keynote speech to delegates of Organization of Islamic Conference, Kuala Lampur, Malaysia www.OIC-ICO.org accessed October 25, 2001.

Minna, M. (April 28, 2000). Closing plenary address to the World Education Forum, Dakar, Senegal www.unesco.org/education/efa/wef 2000/speeches/mminna.shtml accessed October 13, 2001.

Moulds, L. (1996). Using distance learning in the training of adult learners. ED Journal, Volume 10(6), June 1996. www.electroniclearning.edu accessed September 17, 2001.

Okwembah, A. (April 17, 2000). IT centre brings world to sleepy Nabweru.”The East African www.nationaudio.com/news/eastafrican/17042000/features/pa5.html accessed October 16, 2001.

Senegal, World Bank Group: World Links for Development. www.worldbank.org/worldlinks/english/html/senegal.htm accessed September 27, 2001.

Short, C. (April 27, 2000). Universal primary education: The key to poverty reduction. Speech to World Education Forum, Dakar, Senegal www.unesco.org/education/efa/wef_2000/speeches/clare short.shtml accessed October 13, 2001.

SIL International [Organizational website] www.sil.org accessed November 9, 2001. 
Sperling, G. (April 28, 2000). Remarks to the International Consultative Forum on Education for All, Dakar, Senegal www.unesco.org/education/efa/wef 2000/speeches/sperling.shtml accessed October 13, 2001.

UNESCO [Organizational website] www.unesco.org accessed October 13, 2001.

UNFPA [Organizational website] www.unfpa.org accessed October 20, 2001.

UNICEF [Organizational website] www.unicef.org accessed October 13, 2001.

Wolfensohn, J. (April 27, 2000). A TIME FOR ACTION: Placing education at the core of development. Plenary Address to the World Education Forum, Dakar, Senegal www.unesco.org/education/efa/wef_2000/speeches/wolfen.shtml accessed October 13, 2001.

Women's Net [Organizational website] www.womensnet.org accessed October 1, 2001.

World Bank Group [Organizational website] www.worldbank.org accessed October 1, 2001.

Senegal, World Bank Group: World Links for Development. www.worldbank.org/worldlinks/english/html/senegal.htm accessed September 27, 2001.

Work like an Egyptian. (November 14, 2000). Reuters www.wired.com/news/print/0,1294,40171,00.html accessed November 8, 2001.

\section{Biographies}

Kimberley Leahy is a Ph.D. Student in Mass Communication at the Florida State University, with an emphasis on the intersection of innovation and public policy specific to wireless communication. In 2001, Ms Leahy earned her MBA from St Joseph's University, with a concentration in Information Systems. She received her BS in Business Administration in 1997 from Indiana University of Pennsylvania, with a major in Marketing and a minor in Economics. This is Ms Leahy's first publication.

Dr. Ira Yermish holds a Ph.D. in Information Systems from the University of Pennsylvania, an MBA from Stanford University, and a BS from Case Western University. Dr. Yermish is an Associate Professor of Information Systems at St Joseph's University, as well as the principal and founder of a successful IT consulting firm in Philadelphia. Dr. Yermish has been published extensively in his field. 